\title{
Does Conservative Surgical Management of Early Stage Cervical Cancer Represent a Persistent Dilemma in Young Patients?
}

\author{
Georgios Androutsopoulos*1, Ioannis C Kotsopoulos², Porfyrios Korompelis ${ }^{2}$ and Georgios Decavalas ${ }^{1}$ \\ ${ }^{1}$ Department of Obstetrics and Gynecology, University of Patras, Medical School, Greece \\ ${ }^{2}$ Northern Gynaecological Oncology Centre, Queen Elizabeth Hospital, United Kingdom
}

Submission: March 21, 2017; Published: March 30, 2017

*Corresponding author: Georgios Androutsopoulos, Assistant Professor, Department of Obstetrics and Gynecology, University of Patras, Medical School, Rion 26504, Greece, Tel: +306974088092; E-mail: androutsopoulos@upatras.gr; androutsopoulosgeorgios@hotmail.com

\section{Editorial}

Nowadays, cervical cancer (CC) is the most common malignancy of the female reproductive system and the fourth most common cancer in general female population [1,2]. The disease is more prevalent among young women and related directly with persistent HPV infection [1,2]. Especially in developing countries CC represents almost $12 \%$ of all malignancies in women [1,2]. Additionally, the mortality rate from CC is almost 10-14 times higher in poor and less developed countries (Melanesia, Middle and Eastern Africa), when compared with developed ones (Western Asia, Western Europe, Australia and New Zealand) $[1,2]$.

Based on recently published recommendations and guidelines, the primary management of CC depends mainly on disease stage and could be either surgical or non-surgical (radiotherapy, chemoradiotherapy) [3-5]. Nevertheless, the type and extend of surgical procedure and the type of non-surgical approach should be thoroughly individualized according to disease stage, histologic subtype, fertility issues and patient's general performance status [3,5-7]. According to the abovementioned, conservative management could be offered in well selected young patients with early stage CC and intense desire for future fertility, after extensive and detailed counseling regarding disease recurrence, future fertility, pregnancy complications and perinatal issues [3,5-9]. In contrast, conservative therapeutic approach should be avoided in CC patients having rare histologic subtypes with aggressive or possibly aggressive clinical behavior (small cell neuroendocrine carcinoma, minimal deviation adenocarcinoma and gastric type adenocarcinoma) $[3,10,11]$.

Patients with FIGO stage IA1 disease without lymphovascular space invasion (LVSI), could be treated with cervical cone excision only $[3,5-7,12-14]$. This is based on the fact that in this patients' subgroup, the risk of lymphatic metastasis or recurrent disease is very low $(0.8 \%$ and $0.6 \%$ respectively) [1518]. The procedure could be performed with cold knife or loop and both ectocervix and endocervical canal should be removed in a single specimen having at least $3 \mathrm{~mm}$ clear margins for preinvasive or invasive disease $[3,5,7]$. In most cases, cold knife conization (CKC) provides many advantages compared to loop electrosurgical excision procedure (LEEP), regarding accurate evaluation of marginal status in conization specimens $[7,19,20]$. However in case of cone margin involvement, cervical conization should be repeated or radical trachelectomy should be offered and discussed with the patient $[3,7]$.

Patients with FIGO stage IA1 disease and LVSI, could be treated with cervical conization or radical trachelectomy, with additional pelvic lymph node dissection and sampling of paraaortic lymph nodes [3,5-7,13,14,21-23]. In this patient subgroup, the risk of lymphatic metastasis or recurrent disease is significantly higher (8.2\% and $3.1 \%$ respectively) [7,16-18]. Particularly in cases with marginal involvement, conization should be repeated or radical trachelectomy should be offered and discussed with the patient $[3,7,22,23]$.

Likewise, patients with FIGO stage IA2 disease, could be treated with radical trachelectomy, pelvic lymph node dissection and sampling of paraaortic lymph nodes [3,5-7,9,22,24,25]. This is based on the fact that the risk of lymphatic metastasis is almost $8 \%$ in this stage, while the risk of recurrent disease is essentially greater in the LVSI subgroup (15.7\% and $1.7 \%$ respectively) $[7,15,16,18,26]$. In addition, cervical conization with pelvic lymphadenectomy and paraaortic lymph node sampling is an alternative therapeutic approach for patients with FIGO stage IA2 disease and no cone margins or lymph node involvement [3,5-7,14,21,22]. 
Patients with FIGO stage IB1 disease, are in even higher risk for lymphatic metastasis (14.9\%) and disease recurrence $[15,27]$. Tumor size more than $2 \mathrm{~cm}$, depth of stromal invasion greater than $50 \%$ and presence of LVSI, represent some dismal prognostic factors $[24,25]$. Consequently, only in patients with FIGO stage IB1 disease and tumor size up to $2 \mathrm{~cm}$, should be offered fertility sparing approach with radical trachelectomy, pelvic lymph node dissection and sampling of paraaortic lymph nodes $[3,5-7,9,22,24,25,28]$. The procedure of radical trachelectomy could be performed via vaginal or abdominal approach, as there are no important differences regarding oncologic outcome [7,29]. Moreover, some studies evaluating the role of abdominal radical trachelectomy in FIGO stage IB1 CC with tumor size more than $2 \mathrm{~cm}$, are very promising [30,31].

In conclusion, the conservative management of early stage $\mathrm{CC}$ is possible in well selected young patients with intense desire for future fertility [3,5-7]. However, all of them should have a thorough preoperative assessment and a detailed counseling regarding disease recurrence, impaired cervical function, fertility issues, miscarriages and preterm labor $[7,9]$.

\section{References}

1. WHO (2012) Estimated cancer incidence, mortality and prevalence worldwide in 2012. GLOBOCAN.

2. Ferlay J, Soerjomataram I, Dikshit R, Eser S, Mathers C, et al. (2015) Cancer incidence and mortality worldwide: sources, methods and major patterns in GLOBOCAN 2012. Int J Cancer 136(5): E359-386.

3. NCCN (2017) Clinical Practice Guidelines in Oncology: Cervical Cancer NCCN.org 1-83.

4. ESGO (2010) Algorithms for management of cervical cancer. ESGO.org 1-8.

5. Colombo N, Carinelli S, Colombo A, Marini C, Rollo D, et al. (2012) Cervical cancer: ESMO Clinical Practice Guidelines for diagnosis, treatment and follow-up. Ann Oncol 23(Suppl 7): vii27-32.

6. Chuang L, Temin S, Berek J (2016) Management and care of women with invasive cervical cancer: American Society of Clinical Oncology Resource-Stratified Clinical Practice Guideline Summary. I Oncol Pract 12(7): 693-696

7. Androutsopoulos G, Kotsopoulos I, Michail G, Decavalas G (2017) Fertility sparing approach in young patients with early stage cervical cancer. Obstet Gynecol Int J 6(2): 00197.

8. Bentivegna E, Gouy S, Maulard A, Chargari C, Leary A, et al. (2016) Oncological outcomes after fertility-sparing surgery for cervical cancer: a systematic review. Lancet Oncol 17(6): e240-253.

9. Ramirez P, Pareja R, Rendon G, Millan C, Frumovitz M, et al. (2014) Management of low-risk early-stage cervical cancer: should conization, simple trachelectomy, or simple hysterectomy replace radical surgery as the new standard of care? GynecolOncol 132(1): 254-259.

10. Viswanathan A, Deavers M, Jhingran A, Ramirez P, Levenback C, et al. (2004) Small cell neuroendocrine carcinoma of the cervix: outcome and patterns of recurrence. Gynecol Oncol 93(1): 27-33.

11. Young R, Clement P (2002) Endocervical adenocarcinoma and its variants: their morphology and differential diagnosis. Histopathology 41(3): 185-207.

12. Sevin B, Nadji M, Averette H, Hilsenbeck S, Smith D, et al. (1992) Microinvasive carcinoma of the cervix. Cancer 70(8): 2121-2128.
13. Wright J, Nathavith Arana R, Lewin S, Sun X, Deutsch I, et al. (2010) Fertility-conserving surgery for young women with stage IA1 cervical cancer: safety and access. Obstet Gynecol 115(3): 585-590.

14. Winter R (1998) Conservative surgery for microinvasive carcinoma of the cervix. J Obstet Gynaecol Res 24(6): 433-436.

15. Pecorelli S (2009) Revised FIGO staging for carcinoma of the vulva, cervix, and endometrium. Int J GynaecolObstet 105(2): 103-104.

16. Benedet J, Anderson G (1996) Stage IA carcinoma of the cervix revisited. Obstet Gynecol 87(6): 1052-1059.

17. Ostor A (1995) Pandora's box or Ariadne's thread? Definition and prognostic significance of micro invasion in the uterine cervix. Squamous lesions. Pathol Annu 30(Pt 2): 103-136.

18. Mota F (2003) Microinvasive squamous carcinoma of the cervix: treatment modalities. Acta Obstet Gynecol Scand 82(6): 505-509.

19. Miroshnichenko G, Parva M, Holtz D, Klemens J, Dunton C (2009) Interpretability of excisional biopsies of the cervix: cone biopsy and loop excision. J Low Genit Tract Dis 13(1): 10-12.

20. Kim M, Kim M, Kim J, Chung H, Park N, Song Y, et al. (2012) Loop electrosurgical excision procedure findings for identification of patients with early-stage cervical cancer suitable for less radical surgery. Int J Gynecol Cancer 22(7): 1214-1219.

21. Yoneda J, Braganca J, Sarian L, Borba P, Conceicao J, et al. (2015) Surgical treatment of microinvasive cervical cancer: analysis of pathologic features with implications on radicality. Int J Gynecol Cancer 25(4): 694-698.

22. Abu-Rustum N, Sonoda Y (2010) Fertility-sparing surgery in earlystage cervical cancer: indications and applications. J Natl Compr Canc Netw 8(12): 1435-1438.

23. Plante M, Gregoire J, Renaud M, Roy M (2011) The vaginal radical trachelectomy: an update of a series of 125 cases and 106 pregnancies. Gynecol Oncol 121(2): 290-297.

24. Park J, Joo W, Chang S, Kim D, Kim J, et al. (2014) Long-term outcomes after fertility-sparing laparoscopic radical trachelectomy in young women with early-stage cervical cancer: an Asan Gynecologic Cancer Group (AGCG) study. J Surg Oncol 110(3): 252-257.

25. Diaz JP, Sonoda Y, Leitao M, Zivanovic 0, Brown C, et al. (2008) Oncologic outcome of fertility-sparing radical trachelectomy versus radical hysterectomy for stage IB1 cervical carcinoma. Gynecol Oncol 111(2): 255-260.

26. Buckley S, Tritz D, Van Le L, Higgins R, Sevin B, et al. (1996) Lymph node metastases and prognosis in patients with stage IA2 cervical cancer. GynecolOncol 63(1): 4-9.

27. Chandacham A, Charoenkwan K, Siriaunkgul S, Srisomboon J, Suprasert $P$, et al. (2005) Extent of lymphovascular space invasion and risk of pelvic lymph node metastases in stage IB1 cervical cancer. J Med Assoc Thai 88(Suppl 2): S31-36.

28. Cao D, Yang J, Wu X, Chen Y, Li L, et al. (2013) Comparisons of vaginal and abdominal radical trachelectomy for early-stage cervical cancer: preliminary results of a multi-center research in China. Br J Cancer 109(11): 2778-2782.

29. Schneider A, Erdemoglu E, Chiantera V, Reed N, Morice P, et al (2012) Clinical recommendation radical trachelectomy for fertility preservation in patients with early-stage cervical cancer. Int J Gynecol Cancer 22(4): 659-666.

30. Wethington S, Sonoda Y, Park K, Alektiar K, Tew W, et al. (2013) Expanding the indications for radical trachelectomy: a report on 29 patients with stage IB1 tumors measuring 2 to 4 centimeters. Int J Gynecol Cancer 23(6): 1092-1098. 
31. Lintner B, Saso S, Tarnai L, Novak Z, Palfalvi L, et al. (2013) Use of abdominal radical trachelectomy to treat cervical cancer greater than $2 \mathrm{~cm}$ in diameter. Int J Gynecol Cancer 23(6): 1065-1070.

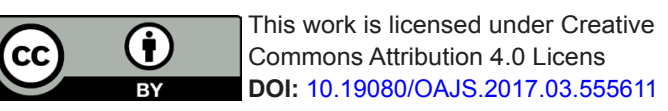

\section{Your next submission with Juniper Publishers will reach you the below assets}

- Quality Editorial service

- Swift Peer Review

- Reprints availability

- E-prints Service

- Manuscript Podcast for convenient understanding

- Global attainment for your research

- Manuscript accessibility in different formats ( Pdf, E-pub, Full Text, Audio)

- Unceasing customer service

Track the below URL for one-step submission https://juniperpublishers.com/online-submission.php 